\title{
Terrorism as Impediments To Democracy In Nigeria
}

\author{
Charas Madu Tella \\ Department of Political Science Federal University Dutse, Nigeria \\ Umar Mohammed Bello \\ Department of Political Science Federal University Dutse, Nigeria \\ Shehu M. Liberty \\ Department of Public Administration University of Maiduguri.
}

\begin{abstract}
Terrorism has been conceptualized as an act of violent conflict, armed conflict, insurgency, bombing, kidnapping, assassination, sabotage and a series destructive activities leading to the use of physical force against another person or group aimed at either causing death, temporal or perpetual injury or drawing government's, groups' or individual attention for relevance and recognition. The word terrorism did not, however, feature more prominently in the minds of people until after the US 9/11 World Trade Center bombings. These acts were not only to create panic, fear and anxiety but also to undermine security and political leadership of the country targeted. Since the September 11th, terrorism has continued to spread and have taken a new dimension across the globe and Nigeria was, thus, not an exception. The objective of this research is to examine the effects of terrorism and violence on development of democracy in Nigeria. The research employed primary and secondary data. 300 questionnaires were distributed, retrieved and analyzed using chi-square techniques. The findings revealed among other things that terrorism has consequent effects on the development of democracy in Nigeria. Finally, the research recommended that elections and its myriad of processes must be free, fair and transparent in addition to being devoid of violence and conflicts. The culture of stuffing ballot boxes with paper constitutes a serious challenge and the outcome in most situations contradict the choice of the electorate. Therefore, the electoral processes should be more fervently strengthened to avoid crises and their related consequences.
\end{abstract}

Keywords: terrorism, violence, conflicts, democracy in Nigeria, challenges of democracy

\section{INTRODUCTION}

Since the restoration of democratically elected government in Nigeria in 1999, the Nigerian government was faced with challenges of terrorism, conflict and violence and which have jointly threatened the protection of its citizens. These threats sometimes came from the state itself or from non-state actors. Organized crime, trafficking, civil unrest and terrorism have supplanted armed conflict as the main sources of violence and insecurity within many polities apart from natural disasters as additional source of insecurity. Insecurity obtains in a form of arm conflicts, especially as they may not only generate, but often exacerbate pre-existing ones. Equally, violence and human rights concerns are frequent occurrences in Nigeria. Insecurity invariably emerges when armed conflict, social and criminal violence inevitably exposes the population to widespread human rights violations, including extrajudicial killings, torture and ill-treatment, disappearances and arbitrary detention among others.

The prolonged military administrations and a couple of daunting challenges immediately popped up to add to the country's checkered history of terrorism, violence, conflicts. For 
example, the sudden spate of lethal inter-communal violence (LICV) characterized by violent ethno-religious crises erupted across all portions of the country. However, in the wake of these eruptions, the population was left economically devastated and socially traumatized, arising out of the apparent destruction of both lives and property. According to Mallam (2009), it was estimated that "between 1999 and 2015, there have been at least 387 terrorist acts, 198 ethnoreligious conflicts and 539 political clashes in Nigeria".

The situation was compounded by the fact that since Nigeria got her independence from Britain in 1960, the country had been governed by military administrations for thirty-two (32) out of fifty-six (56) years of its existence as an independent entity . Subsequently, with the emergence of the Third Republic and the subsequent Fourth Republic, expectations were high and the prevailing attitude among the citizenry was positive and the feeling of every Nigerian was simply "here comes a government that would provide everything" as Juan (1996) opined. Also, majority of Nigerians equally believed that the country's struggling economy would finally improve through equity, justice and fair play.

According to Alozieuwa (2012), the average Nigerian today encounters frustration, disillusionment and psycho-moral dislocation owing to the failure of government to deliver the expected fruits of democratic governance, more especially in terms of stemming the tide of unemployment, checkmating the increase of poverty, combating corruption and injustice in the distribution of the nation's resources. Any shortcoming in attending to these naughty issues would only end up promoting further economic dislocations, distrust and disunity amongst the divergent ethnic nationalities.

Although, during democratic dispensations, leaders are supposed to be elected at regular intervals while electorates can choose among alternative candidates in practice, at least two political parties that have a chance of winning are needed to make such choices meaningful; It is against this backdrop that the Nigerian Independent Electoral Commission (INEC) was tasked with the responsibility of regulating the bargaining process of unbiased legitimating of the likely outcome. This is to enable the Nigerian citizenry to participate in the electoral process freely and transparently in addition to enjoying the associated benefits of basic freedom of speech, freedom of the press, freedom to associate and for lawful assembly and organization. These principles constitute the basis upon which democracy and democratic governance is enthroned in Nigeria and elsewhere. To further buttress this, Edigheji (2005) is equally of the opinion that legitimate and democratic government should be characterized by free and fair elections, existence of more than one political party and fundamental human rights. Similarly, Jamo (2013) also noted that separation of powers, political tolerance, accountability, transparency, rule of law and equality are essential features of democratic governance. Unfortunately, in Nigeria, the reverse is the order, more so, as popular participation in the process of governance still remains limited just as is the case in terms of equality among citizens, sovereignty of the people, the promotion and protection of human rights and essential freedoms, the rule of law, and separation of powers between the three arms of government.

\section{Objectives of the Study}

i. The general objective of this study is to assess the impact of terrorism on democracy in Nigeria.

ii. To examine whether or not terrorism has contributed to the myriad of challenges being faced by democracy in Nigeria.

iii. To recommend as appropriate measures towards improving the consolidation of democracy in Nigeria. 


\section{Hypothesis:}

Ho1 terrorism contributed to poor consolidation of democracy in Nigeria

Ho2 poor consolidation of democracy in Nigeria cannot be attributed to terrorism

Ho1 social factors such as ethnicity, religion, violence perpetrated by political thugs etc. in Nigeria have jointly contributed to poor consolidation of democracy in Nigeria

Ho2 lack of consolidation of democracy in Nigeria cannot be attributed to social problems

\section{CONCEPTUALIZATION OF TERRORISM}

According to the contemporary social scientists terrorism, insurgency, militancy, and violence are issues of national security challenges cutting across many disciplines covering military protection, surveillance, protection of national values and human rights, among others. This targeted violence, increased lawlessness, escalating sectarian tensions and the state's inability to protect its citizens, and its military's own contribution to human rights violations, has raised significant alarm as to whether or not the international community is also witnessing the mass atrocities being committed.

Though the word terrorism was first used in France to describe a new system of government adopted during the French Revolution (1789-1799), the words now have a decidedly negative connotation. There have been numerous efforts by many social scientists at defining terrorism as violent conflict, armed conflict, bombing, kidnapping, assassination, threatening action and destructions leading to the use of physical force, power against another person or group with likelihood of resulting in injury or death (Afegbua 2010). Today, the word terrorism which is a major dimension of insecurity is defined by the United States Law Code as:

"...to mean premeditated, politically motivated violence perpetrated against noncombatant targets by sub-national groups or clandestine agents".

International terrorism refers to terrorism involving citizens of the territory of more than one country. This is to say that international terrorism refers to those acts in which the terrorists cross national frontiers to carry out attacks, or attack foreign targets at home such as bombing embassies, or hijacking air or sea liners (Lesser, 1999:6). However, terrorism did not gain wider popularity and publicity until September 11, 2001 bombing of the World Trade Centre (WTO) in United States, alleged to have been master-minded by Osama bin Laden. All terrorist acts involve violence or equally important, the threat of violence and these violent acts are committed by non-state armed actors.

The aim and objective of the terrorists attempt was not only to create panic, fear and anxiety but also to undermine confidence in the government and political leadership of their target country. Terrorism is therefore designed to have psychological effects that reach far beyond its impact on the immediate victims or object of an attack. Although terrorism according to Ogunyemi, B. (2011), is not easily defined, but:

"...may be said to be the use of force, usually violent, as a means of coercing a target population to submit to the will of the terrorists. This is intended to elicit or maximize fear and publicity, making no distinction as to combatants and noncombatants in a conflict".

Therefore, terrorism by its nature is political because it involves the acquisition and use of power for the purpose of forcing others to submit, or agree, to the demands of the terrorists. A terrorist attack is aimed at generating publicity and focusing attention on the organization behind the attack and it is also designed to create this power. 


\section{CONFLICT}

Accordingly, a conflict situation is characterized by the inability of those concerned to iron out their differences and reach an agreement on issues of common interest. This inability manifests in one form of protest or the other such as strikes and other work disruptions (slowdowns, sabotage and planned absenteeism). Ejiogu (1990) also perceived conflict as mutual hostility and all kinds of opposition or antagonistic interaction including disagreements or controversies about ideas, values, and ways of life.

Conflict can further be described as a situation or condition of disharmony in an interactive process. Banks (1984:100), claim that a situation of conflict is one in which the activity of one is actually or forcibly imposed at unacceptable costs, materials or psychic, upon another. For conflict to occur, Banks postulated three fueling factors which are intensity and salience of the issue at stake, the status and legitimacy of the parties and the clustering of interests and coincidence of cleavages within a community. These factors determine the extent to which conflict can stretch. Imobighe (1992:32) points out that conflict is not limited to any particular level of interaction. In other words, it could occur at any level of human interaction and it often manifested in violent activities.

Conflicts are common and more often than not can be avoided in all human societies and they occur because the society is made up of people with differing interests, values and opinions. In most societies, conflict occur when both parties in a state of independence perceive and view and believe that their interest and goals are either at jeopardy or cannot be realized or achieved due to some factors. It is only natural as expressed by Afebua (2010) that where there is inequality in access to the control of resources, for example political power, there would be discontent, opposition and controversy. Romm (1993) opined that a nation is said to be secured when it does not have to sacrifice its legitimate interest to avoid war, and is able, if challenged, to maintain them by war. He further defined it as the absence of threats to acquired values and the absence of fear that such values will be attacked. Implicitly therefore, national security is the ability of a nation to preserve its internal values from any external threats or aggressions. According to Musdapher cited by Allswell (2014):

"More than ever before, in the history of Nigeria, the scourge of terrorism poses great challenges to the Nigerian state. Our slide into anarchy has assumed a dangerous center stage, perhaps beyond the capacity of our security agencies to deal with the menace effectively".

\section{LITERATURE REVIEW}

Although in Nigeria the primary aims and objectives of Boko-Haram acts and insurgency still remain unclear, the increasing sophistication of the group's attacks and the acceleration with which it was labeled as one of the deadly terrorist organizations and its lethality underline the importance of a strong, coherent response to the issue and the consequences of the country's failure to mount such a response. This placed the Boko Haram terrorist act as one of the most significant conflicts not only in Nigeria but also in the West African sub-region. According to Nathaniel, Peter, Lewis and Hilary (2014), the casualties are now running to more than double that Afghanistan, and substantially higher than the casualties in Iraq since the beginning of the Iraqi conflict in 2003.

This is because it was estimated that about 3,120 civilian and military casualties were recorded in Afghanistan last year and in Iraq in 2013 compared to 4,207 fatalities estimated in 2011 only in the wake of the surge. The worsening conflict already has caused more casualties this year than the world's most publicized contemporary wars. Today, in Nigeria the conflicts news in Sudan, Somalia, and Democratic Republic of Congo in central Africa, Iraq, Gaza and Ukraine 
crises have been overshadowed in recent months by the news of Boko-Haram and Militancy in the Niger Delta. Consequently, the greatest causalities in this deadly terrorist acts and wars are the innocent impoverished masses that do not have the means to secure themselves and their properties.

Terrorism and other related violent activities are indeed part of the consequences of poor governance. Cronin (2011) asserted that "The current wave of international terrorism, characterized by unpredictable and unprecedented threats from non-state actors is not only a reaction to terrorism but also facilitated violence. In other words, terrorism and other related violent activities such as Boko-Haram insurgency are consequences of corruption and unemployment.

Cronin further asserted that the gap between the rich and poor countries has expanded over the last 20 years owing to the effects of international terrorism, thereby fuelling animosities and violence among the poor marginalized and colonially exploited countries predominately located in the Third World. Cronin, thus, again concluded that this resulted in aggression in the form of terrorism in the Third World against the exploitative policies of the colonizing powers that disarticulated their economy and left them pauperized.

This ultimately means, terrorism can be linked to the theory of deprivation and as a manifestation of conflict. According to Paul Martin, Canadian Minister of Commerce, the September 11, 2001 terrorist attack was aimed at the destabilization of the economy of the USA. This indeed happened: He concluded by saying that:

"For the terrorist, however, the aim of their criminal act was not only the destruction of life; they were seeking to destroy our way of life. The terrorist did not choose their target randomly. New York's World Trade Center stood at the heart of the international financial district. It was a symbol of accomplishment and confidence. It was targeted for that reason. The terrorist sought to cripple economic activity, to paralyze financial relations, to create new barriers between economies, countries and people".

While supporting the above statement, Olubolade, as cited in Abimbola, and Adesote, (2012) opined that: "I will rather believe that today, we are facing new threats different from what we used to face before the 1960s" and he further concluded thus "this threats that confront us, we will find solutions to them; it is now a period to look forward and overcome the challenges that face us."

It is against this development, William, (2006) and Aydinli, (2008), in their opinion concluded that these terrorists and insurgency groups have become more powerful than the Nigerian security. This threat has been exemplified by the September 11, 2001 as pointed out by Duru and Ogbonnaya, (2010). They elaborated that the bombings of the World Trade Centre (WTC) in the United States by the Al-Qaeda terrorist network served as an emerging trend. Consequently, the attacks have resulted in the killings of hundreds of people, rendered more than a million people homeless and destroyed billions of dollars' worth of properties. They further commented that:

"What should be understood about terrorists method of operation is that any evil doer will look for a justifying reason, whether tenable or untenable, to indulge in evil deed. And the reason often given is one which appeals to people of like minds at least in the neighborhood. This is to elicit their sympathy and support. The common denominator among all terrorists is the theory of "using what you have to get what you want". 
Similarly, according to African perspective terrorism is defined as "any act which is a violation of the criminal laws of a state party and which may endanger the life, physical integrity or freedom, or cause serious injury or death to any person, any member or group of persons or causes or may cause damage to public or private property, natural resources, environmental or cultural heritage. On the other side, the Nigerian definition of terrorism is:

"...anyone who is involved or who causes an attack upon a person's life which may cause serious bodily harm or death; kidnapping of a person; destruction to a government or public facility, transport system, an infrastructural facility including an information system, a fixed platform located on the intercontinental shelf, public place or private property likely to endanger human life or result in major economic loss".

\section{DEMOCRACY IN NIGERIA}

The model of democracy that is popular in this age of globalization is liberal democracy. It is a descriptive term that is synonymous with majority rule, and also associated with democratic consolidation and good governance. Since the coming of the democratic elected government of the third Republic in 1999, transitions have been periodic through elections at all levels. However, the effort to attain the highest level of democratic consolidation and good governance has been made but not yet crowned with much success. For example, the numerous Nigerian political transitions of 2003, 2007, 2011 and 2015, have not registered considerable progress in the years compared to the deep-seated problems of structure, institutional weaknesses, and poor performance that are jeopardizing the democratic experiment and, thus, constituting themselves into herculean challenges against the nation's quest for national integration.

The periods under review, there have been successful four government transitions of administrations from civilian to civilian. For example, from 1999-2007 was the Administration of President Olusegun Obasanjo, 2007-2011, Yar'adua/Jonathan Administration, 2011-2015) Jonathan Administration lasting up to 2015 when the Buhari Administration took over. Similarly, the country has equally passed through series of legislative hurdles visible at the center and the various component units. Consequently, some of the transitions have been characterized by monumental irregularities and malpractices the magnitude of which increased with every election process, especially at the aftermath of 2011 which was characterized by extensive conflicts and violence in some parts of the country. Many observers have argued that the real reason for the escalation of terrorism, violence and conflicts is the scramble for land, scarce resources and the struggle for political clout. Poverty, joblessness and corrupt politics drive extremists from both sides to commit horrendous atrocities.

According to Dawood (2015), these were caused by Nigeria's political class as they are fragmented and contentious, their institutions largely feeble or dysfunctional. He further stated that, ordinarily, nations are expected to express themselves in a manner to typify any one category of a nation-state. Mbachu eruditely (1990), in his opinion, stated that democracy allows conflicts in society to be resolved by rational arguments and persuasion rather than by violent coercion. The empirical evidence from Nigeria suggests that it seeks to employ both formulations - rationality and coercive forces in some situations. For instance, while it claims to offer equal citizenship rights to all citizens irrespective of their cultural and numerical attributes, it, at the same time, defines the nation in cultural terms and gives priority of some kind to the major ethnic groups over the minority groups.

It was also argued that where equal consideration is expected in an avowedly ethnically and regionally neutral meritocracy, what obtains is discrimination against individuals, groups, ethnic, and regional among others. This attracts varying degrees of sentiments against the state 
and its leadership, thereby undermining the democratic principles of equity, justice, fair play and transparency against ethnic relations and national integration. As a result, Ajayi A. K. (2015) concisely argued that:

"Elections and democratic practice in the third and fourth Republics was characterized by electoral malpractices, political intolerance, economic mismanagement, using political office as gateway to personal enrichment, political thugery, lack of intra party democracy, insecurity, manipulation of religion and ethnicity to achieve selfish political ambitions and other countless misdemeanors were the order of the day"

\section{CHALLENGES UNDERMINING DEMOCRACY IN NIGERIA - A BROAD FRAMEWORK}

The major challenges undermining consolidation of democracy in Nigeria are the hydraheaded issues of corruption, poverty, insecurity, unemployment, indiscipline, ethnicity, religion among others. The characteristics of the Nigerian State some observers have noted are responsible for Nigeria's deepening ethno-religious conflicts, wars and crises. The plural nature of Nigerian state emanate from constant feeling of distrust between the component units and the fear of one ethnic or religious group emerging as most dominant. For example, after the civil war, there was still much ethnic suspicion and distrust that existed prior independence in 1960 which provoked the military coup d'état of 1966, the civil war of 1967, the annulment of the June 12, 1993 presidential elections and other incessant ethno-religious crises that are presently threatening the very foundation of our embryonic democracy and indeed our national integration and existence under a federal context.

Since the return of democracy, Nigeria has experienced so many ethno-religious crises, sectarian violence, among which are the Shagamu Yoruba/Hausa-Fulani conflict, Aguleri, Umuleri and Umuoba Anam conflicts in Anambra State; Ijaw/Itsekiri crisis over the location of Local Government headquarter; the Jukun/Tiv crises, the 2011 post-election violence, Herdsmen crises in Benue, Nasarawa, Enugu and Imo. Others are religious riots in Bauchi, Borno, Adamawa, Kano, Kaduna, Plateau, Abuja, Benue, Kaltungo/Billliri ethnic clashes etc across the country. This shows that our democracy is under siege. Furthermore, there was also much political violence which at the end of day created fear in the minds of many electorates, thereby encouraging voter apathy. It was against this backdrop that Dauda and Avidime (2007) opined that the current security situation in the country is a major obstacle to the consolidation of democracy. This view is again strongly reinforced by Adeyemi (2006) when he noted that:

"Ethnic and religious issues are part of the most recurring issues in Nigeria's body politic. The issue has permeated the landscape since the colonial period and up till the present time, there seems to be no solution in sight to the accompanying conflicts of ethnic rivalry and religious intolerance. The dominant and minority ethnic groups treat each other with suspicion and the different religious worldview clash at the slightest provocation".

\section{THE BRUNT OF TERRORISM ON DEMOCRACY IN NIGERIA}

Since the World Trade Centre bombings in 2001, the average American has been awaken to the grim reality that even a major power like the U.S. can be effectively threatened as stated by Jennifer (2009). However, the threat of another terrorist attack continues to loom in the minds of U.S. citizens and those of other Western nations. In the case of the US in particular and more especially during election years, the terror threat level is profoundly elevated. Similarly, in Nigeria and North-East in particular, some terrorist threats and their heinous consequences are now gradually spreading across the West African countries and even beyond. It is therefore critical that we best understand and appreciate how these conditions of terrorism and their 
implicit threats affect individuals' political evaluations, attitudes, and behaviors. Consequently, it is worrisome to see that in Nigeria today, terrorism influences individuals' evaluation and choice of leaders more especially in places like Borno state where the Boko-Haram attacks was and still adjudged as very devastating.

In places like Borno and other neighboring states during the 2015 general elections, so many people were not able to participate in the election process as these areas were completely under the control of insurgents and impliedly forcing many people to migrate out of the affected areas because of lingering fear of violence. While some people have developed voter apathy, others have even lost confidence in the government more so, as it relates to protecting the security of their lives and properties. This is likely to make domestic terrorism rise to an exponential level. On the other hand, an increase in terrorist activities is likely to cause a decline in the overall economic activity as Blomberg et al. (2004) observed. Blomberg (2004) further declared that this has by all means affected the state in very many ways and so also the people of the area at large.

In another development, the general work attitudes of civil servants in the violence prone state(s) has made work extremely slow within public sector bureaucracies and many at times a lot remained unattended. Furmanek (2004) viewed attitude to work by civil servants in terms of "to have" and in terms of "to be". In Maiduguri, the State capital, where it was presumed that relative peace and security protection has returned, most of the businesses have either been operating for half a day's period or not carried out at all. As a result, some civil servants took advantage of the security situation by absenting themselves from office for days, weeks or even months. Furthermore, it was evident that some of the civil servants don't report to office due to threat they received while most commercial banks open at $9 \mathrm{am}$ instead of $7 \mathrm{am}$ and close at $2 \mathrm{pm}$ instead of $4 \mathrm{pm}$. Filling stations also open at $8 \mathrm{am}$ and close at $5 \mathrm{pm}$. Similarly, due to the state of emergency, since the governor is not the accounting and chief security officer of the state, no any social and economic activities take place in the night due to the curfew imposed on the state. Consequently, most of the prices of things in Borno state had tripled as it takes transporters more than 12 hours to convey materials from Kano to Maiduguri, a distance can normally takes less than five hours to cover. Added to this is the issue of corruption, as most if not all the commercial buses and lorry drivers have to extensively bribe the security men bordering the States.

According to a publication of the Centre for Democratic Studies (CDS) Mambaya House Kano (2014), the apparent drop in economic earnings may be attributed to the near total collapse of most businesses. Most of businesses were negatively affected by the security challenges. Some of them had to close down totally while others had to retrench their workers to enable them cut down on the number of hours needed for operation. Some had to relocate to other states with their businesses. Similarly, these security challenges, especially the Boko-Haram incursions have reduced drastically government revenue derived from the affected region; reduced tremendously investment and growth of business in the affected places, except for government executed projects. The damaging consequences is in the range of Billions of Naira.

Similarly, the terrorist and insurgency activities have also contributed immensely to the rising cost of essential commodities in the state as a result of difficulties traders experience in transporting their goods and services to the State, as well as acts of extortion perpetrated by the Military and other security agencies. For example, from Maiduguri to Potiskum in Yobe State, there were no fewer than 45 'security' check-points and on each of the check-points, motorists have to pay minimum of 200 Naira. This shows that motorists spent an average of 15,000 Naira per vehicle to convey goods to Maiduguri. Furthermore, due to delay at the check- 
points, the motorist driving bigger vehicles sometimes had to spend an average of 15 hours instead of 8 hours they approximately require to convey goods from Kano to Maiduguri.

\section{THE NORTH-EAST CONTEXT OF THE POLITICAL CHALLENGES}

Government's performance and ability to deliver it objective to its citizen have been reduced significantly. For example, most if not all the civil servants in the northern and central Borno senatorial districts had relocated either to Maiduguri the Borno State capital or to the neighboring countries such as Cameroon, Chad or Niger. Although Nigerian politicians are fond of making false promises for the purpose of gaining people's mandate; in this scenario it became practically difficult. It is in view of that the Borno State Governor Kashim Shettima, claimed that he is not being able to fulfill the larger parts of his promise due to the confusion created in the state by Boko-Haram. It also reached to a point in which all the local government structures have been dismantled completely. Local government chairmen and other political office holders have gone into hiding. Therefore this has a serious effect on the society and people's ways of life.

The structure of the Civil Service in the state has been in a state of disarray as most civil servants posted outside the state had either fled to the state capital of Maiduguri or neighboring states and countries for safety as earlier observed. The situation is the same at the Local Government level as most of the chairmen and other executive officers of the local government had fled their localities except for few in southern parts of the state of Borno. Institutions like the College of Education in Bama, Arabic language Village Ngala, Federal College of Fisheries Baga, and Federal Government Girl's College Monguno were all affected by a prolonged closure. All the primary schools and secondary schools in northern Borno and some affected central areas and southern Borno have remained closed.

It may be interesting to note that a number of civil servants in the affected areas of the State are either in internally Displaced Persons (IDPs) camps or hanging with their friends and relatives outside the State while others not physically seen were presumed to have been killed. In spite of this, their salaries are still sustained even though they remained perpetually absent and implicitly their productivity had either totally declined in places where they could show up once in a while. Arising from the activities of Boko-Haram, some non-Muslim who have not had the opportunity of mingling with the average Muslim or Muslim family are being made to believe that all Muslims are fundamentalist while some are being mischievous about the whole matter. It is unfortunate to note that most of the victims of Boko-Haram are Muslims.

Furthermore, this terrorist activities have made some Nigerians who are outside the community to avoid the State because of the menace of Boko-Haram. Even neighboring States like Adamawa and Yobe are being avoided like a affliction to the extent that some youth serving under the National Youth Service Corp Scheme (NYSC) often reject being posted to these states. Schools that were hitherto popular are not left out as parents avoid sending their children to these volatile areas. Even within the capital city where there is relative security, many parents had fled. Consequently many schools have been closed down due to the activities of insurgents while talented lecturers; teachers have abandoned their schools for other schools in more peaceful states, leading to brain drain of a form.

It was estimated that more than 673 school buildings in Adamawa, Borno and Yobe States are affected by the destructive activities of the insurgents, leading to additional infrastructure deficits in the affected states. Pupils and students are forced to deploy the use of canopies and other make-shift facilities. It is sad to note that a number of children were either killed or have been forced to flee the affected areas, thus, creating additional humanitarian challenges. Again 
as further consequences of the activities of insurgents, school enrollments have severely reduced.

\section{SOCIAL PROBLEM}

There was also the problem of stigmatization arising out of the psyche of victims of rape, unwanted pregnancy, and HIV traceable to contact with the infected members of the BokoHaram group. Due to these terrorist acts, many young girls have become unfortunate victims. Some of the girls escaped from the camp while others were set free after discovering they were pregnant or dangerously sick. As a result, these discharged victims find it difficult to effectively integrate into the normal society. In view of these, some of the girls have developed different types of medical and psychological problems.

Below is a summary of reported attacks, killings and bombing and kidnapping across Borno state from 2011-2014

\section{DATA PRESENTATION AND ANALYSIS}

The following is the formula used to compute the information obtained from the field research using chi-square statistical methods;

Where formula for $\mathrm{x}^{2}=\sum(\mathrm{O}-\mathrm{E})^{2}$

$\mathrm{X}^{2}=$ chi - square

$0=$ observed value

$\mathrm{E}=$ expected value

$\mathrm{Df}=$ degree of freedom

Formula for expected value $(\mathrm{E})=$

Formula for $\mathrm{df}=(\mathrm{r}-1)(\mathrm{r}-1)$ at 0.05 level of significance

Table I Terrorism as impediments to democracy in Nigeria

\begin{tabular}{|l|l|l|l|l|}
\hline Variables & Agreed & Strongly agreed & Disagreed & Total \\
\hline Terrorism & 30 & 42 & 10 & 82 \\
\hline Conflicts & 55 & 62 & 30 & 147 \\
\hline Violence & 20 & 30 & 13 & 63 \\
\hline & 105 & 134 & 53 & 292 \\
\hline
\end{tabular}

Table Ib

\begin{tabular}{|l|l|l|l|l|}
\hline 0 & $\mathrm{E}$ & $0-\mathrm{E}$ & $(0-\mathrm{E})^{2}$ & $\frac{(0-\mathrm{E})^{2}}{\mathrm{E}}$ \\
\hline 30 & 29.49 & 0.51 & 0.26 & 0.01 \\
55 & 52.85 & 2.14 & 4.58 & 0.09 \\
20 & 22.65 & -2.65 & 7.02 & 0.31 \\
42 & 37.63 & 4.37 & 19.10 & 0.51 \\
62 & 67.46 & -5.46 & 29.81 & 0.44 \\
30 & 28.91 & 1.09 & 1.19 & 0.41 \\
10 & 13.86 & -3.86 & 14.90 & 0.08 \\
30 & 20.34 & 9.66 & 93.31 & 4.59 \\
13 & 9.79 & 3.21 & 10.30 & 1.05 \\
\hline $\mathrm{X}^{2}$ & $=$ & & & 13.08 \\
\hline
\end{tabular}

$\mathrm{df}=(\mathrm{C}-1)(\mathrm{C}-1)(3-1)(3-1) 2 \times 2=4$

Decision at 0.05 level of significance $=9.488$

Therefore calculated value $=13.09$

Table value $=9.488$ 
Therefore, since the calculated value was 13.09 while the table value at degree of freedom of 4 at 0.05 level of significance is 9.488 . The calculated value is greater than the table value. As such, we should accept the hypothesis that there is a significant difference between terrorism and consolidation of democracy in Nigeria, which therefore, is alternative hypothesis.

Table 2 Social factors

\begin{tabular}{|l|l|l|l|}
\hline variables & Agreed & Strongly agreed & Disagreed \\
\hline Ethnicity & 37 & 43 & 12 \\
\hline Religion & 52 & 66 & 17 \\
\hline Thuggary & 20 & 30 & 15 \\
\hline & 108 & 139 & 44 \\
\hline
\end{tabular}

Table 2b

\begin{tabular}{|l|l|l|l|l|}
\hline 0 & $\mathrm{E}$ & $0-\mathrm{E}$ & $(0-\mathrm{E})^{2}$ & $\frac{(0-\mathrm{E})^{2}}{\mathrm{E}}$ \\
\hline 37 & & & & \\
52 & 34.34 & 2.66 & 7.08 & 0.21 \\
20 & 50.40 & 1.60 & 2.56 & 0.05 \\
43 & 24.26 & -4.26 & 18.15 & 0.75 \\
66 & 43.80 & -0.80 & 0.64 & 0.01 \\
30 & 64.26 & 1.74 & 3.03 & 0.05 \\
12 & 30.94 & -0.94 & 0.88 & 0.03 \\
17 & 13.86 & -1.86 & 3.46 & 0.25 \\
15 & 20.34 & -3.34 & 11.16 & 0.55 \\
\hline $\mathrm{X}^{2}$ & 9.79 & 5.21 & 27.14 & 2.77 \\
\hline
\end{tabular}

$\mathrm{df}=(\mathrm{C}-1)(\mathrm{R}-1)(3-1)(3-1) 2 \times 2=4$

at 0.05 level of significance $=9.488$

Decision - therefore calculated value $=4.67$

Table value $=9.488$

$\mathrm{H}_{0}=\mathrm{H}_{1}=\mathrm{H}_{2}$

In view of the above analysis, the hypothesis shows that there is a significant correlation between terrorism, ethnicity, religion and the violent activities of political thugs to democracy in Nigeria since the calculated value is more than the table value. As such, we accept the hypothesis. This is obviously seen by the hiccups and challenges in the last six years of democracy in the country and also in which the transitions from 1999-2015 was assumed to have been relatively smooth, notwithstanding some the apparent challenges.

\section{CONCLUSION}

In conclusion, therefore, since the emergence of the elected democratic administration in 1999, the democratic space in Nigeria was characterized by terrorism, conflicts, kidnapping, bombing, ethnic clashes and violence. This was prompted by injustice, impunity, corruption, ethnic and religious intolerance, abuse of office and above all the inability of the political class to demonstrate transparency in governance, failure to do justice and promote equity on issues of common interest. As a result of this 'skewed outlook', the polity was further characterized by all forms of cleavages, protests, strikes and work disruptions, slow-downs, sabotage, hostility and premeditated public bureaucracy absenteeism, overtly heated ideological disagreements and controversies on a variety of issues relating to value systems and ways of life. Indeed, these features are obstacles to the growth of democracy especially when they are recklessly managed, thus, it is pertinent to note that for Nigerian democracy to grow and develop, efforts must be geared towards the promotion of peace and national cohesiveness. Enthroning peace 
and national cohesiveness would undoubtedly help in facilitating not only the growth of democracy in Nigeria but its unalloyed consolidation.

\section{RECOMMENDATIONS}

With the apparent realization that democracy is irrefutably among the most popular systems of government globally, and based on the expectations that it facilitates faster development, government should not reliant its efforts in the fight against insecurity. Thus, Nigerian security operatives should advance towards professionalism is more pro-active towards intelligence gathering and coordinated sharing of intelligence among the various arms. This is in line with global best practices in fighting terrorism and other associated vices.

The issue of money politics, god-fatherism which ushered in desperation, manipulation, assassination and other vices in the polity, should be discouraged with the creation of appropriate penalties and the setting up of cogent institutional and policy frameworks to checkmate them.

In association with the above, civil societies should be encouraged to pressure governments towards institutionalizing democratic reforms and inculcating the idea of national integration and cohesiveness in addition to working fervently towards improving living standards, promoting equality and educating the people against the danger of undue violence perpetrated by political thugs. As part of institutional reforms earlier stated, it is imperative to strengthen the judiciary by firstly ensuring adequacy of remuneration for judicial officers. Secondly, by providing adequate facilities in the administration and dispensation of justice and finally, the judiciary should be given more autonomy in terms of finance and appointment to the bench.

The legislative and executive arms of government are expected to work together whereby one makes the laws and the other implements it according to the laid down procedures and processes, thereby giving the Nigerian presidential system the opportunity to institutionalize the practice of checks and balances especially in relation to upholding public trust and confidence in the workings of government.

The leadership in Nigeria should further strive towards reconciling the demands of different ethnic and religious groups in the country; regard themselves as national leaders and endeavor to be impartial and neutral while carrying out their responsibilities. This will encourage national integration and cohesiveness among the various ethnic and religious groups in Nigeria.

\section{Reference}

Adeyemi L. O. (2006). Ethno-Religious Conflicts and the Travails of National Integration in Nigeria's Fourth Republic. Department of Political Science and Public Administration Adekunle Ajasin University.

Ajayi A. K. (2015). Analyzing the Democracy and Democratic Practice in Nigeria Fourth Republic

Alemika, E. E. O. (2011). Privatization of Security, Arms Proliferation and Electoral Violence in Nigeria in Lai, Olurode and Attahiru Jega (eds.) Security Challenge of Election

Alozieuwa, S.H.O (2012), contends Theories on Nigeria's Security Challenge in the Era of Boko Haram Insurgency. Peace and Conflict Review. Volume 7, Issue 1

http://www.review.upeace.org/index.cfm?opcion=0\&ejemplar=24\&entrada=128

Anyadike, I. and Nkechi, O. (2013), Boko Haram and National Security Challenges in Nigeria; Causes and Solutions: Journal of Economics and Sustainable Development Vol.4, No.5, pp 2222-2855

Aondona, M. (2012). The Major Challenges of Democratic Governance and Political Stability in Africa: Lessons from Nigeria. International Bi-Lingual Journal of Anti-Corruption, Law,Humanities, Social Sciences and Development Studies, 3, 2. 
Aremu, F. A. \& Omotola, J. (2007). Violence as Threats to Democracy in Nigeria under the Fourth Republic, 19992005. African and Asian Studies, Vol. 6 Nos 1-2, 2007. Japan: BRILL

Banks, M.,(1984) Conflicts in World Society, London, Wheatsheaf.

CDHR, (2000), Annual Report on the Human Rights Situation in Nigeria, Lagos:

Dawood, E. O. (2015) Fifteen Years of Democracy, 1999-2014: Reflections on Nigeria's Quest for National Integration African Research Review An International Multidisciplinary Journal, Ethiopia Vol. 9(2), Serial No. 37, April, 2015:59-77 Development Studies,

Edigheji, 0 (2005). A Democratic Developmental State in Africa. A Research Report 105, Centre

Eliagwu J. I. (2005). Nigeria, Yesterday and Today for Tomorrow: Essay in Governance and

Erickson, B. (1985) Life, History and the Historical Moment, New York: Norton \& Co..

Ezeoha, S.L. (2011), “Causes and Effects of Insecurity in Nigeria”. The National Scholar, Vol 8; No. 2 (November) pp 28-28.for Policy Studies. Johannesburg, South Africa 85

Grimshaaw, N (1990) Interpreting Collective Violence, London: Macmillan.

Idris A. J. (2013) Democracy And Development In Nigeria: Is There A Link? Arabian Journal of Business and Management Review (OMAN Chapter) Vol. 3, No.3; Oct. 2013

Igbokwe, J. O. (2012). Democracy and Good Governance in Nigeria: Challenges and Strategies: International BiLingual Journal of Anti-Corruption, Law, Humanities and Development Studies

Iheanacho, E. N. (2012a). Political Leadership: The Bane of Nigerian Development. A paper

Iheanacho, E. N. (2012b). Ethno-Religious Conflicts in Nigeria: A Challenge to National Security. African Journal of Social and Behavioral Sciences, Democratic Governance of Security in Mali: Sustainable Development Challenge.

Imobighe, T.A., (1992) "Human Needs Approach to Conflict Resolution: Neglected Aspects" Nigerian Journal of International Affairs, Vol.18, No.1, 1992.

Jamo, I.A (2009) Democracy and Development in Nigeria: Issues and Challenges. Proceedings of the 2010 International Conference on the Global Financial Crises and Africa's Quest for Development. Faculty of Administration, Ahmadu Bello University Zaria

Jega, A.M. (2004). Democracy, Economic Crisis and Conflicts: A Review of the Nigerian Situation. The Quarterly Journal of Administration. Vol.xxxii, No.1. March.

Juan, B, (1996) Society and Violence, Chicago: Chicago University Press

Mallam B. (2009). National Security as a tool for Sustainable Democracy in Nigeria: An Assessment of Nigerian Police Force. Paper presented at National Conference on Security and Nigeria's Quest for Development.

Management in Nigeria INEC and FES.

Merolla, Jennifer L. and Elizabeth J. Zechmeister. 2009. Democracy at Risk: How Terrorist Threats Affect the Public. Chicago: University of Chicago Press.

http://press.uchicago.edu/ucp/books/book/chicago/D/bo7989509.html

Mimiko, N.O. (1995). Crisis and Contradictions in Nigeria's Democratization Programme.1986-1993, Stebak Books, Akure. of Uyo, 7 August

Ogundiya, I. S. (2010). Democracy and Good Governance: Nigeria's Dilemma. African Journal

Olegbenla, D. K. presented at 1International Conference of the Faculty of Social Sciences, University Society. Jos: Aha Publishing House. 